To cite this article: Ibanoglu MC, Bastemur AG, Karaagac H, Akpinar E, Kara A, Ozcan A, Tapisiz OL, Ustun Y. A postpartum septic case: Differential diagnosis of COVID-19 infection and urosepsis. Turk J Womens Health Neonatol 2021; 3(2): 50-53

\title{
- Case Report
}

\section{A postpartum septic case: Differential diagnosis of COVID-19 infection and urosepsis.}

\section{Postpartum septik olgu: COVID-19 ve ürosepsisin ayırıcı tanısı}

\author{
Mujde Can Ibanoglu*1 $\square$, Ayse Gulcın Bastemur ${ }^{1} \square$ Harun Karagac $^{1} \square$ Ertan $_{\text {Akpınar }}{ }^{\square}$ Aslıhan $\operatorname{Kara}^{1} \square$, \\ Ayse Ozcan²⿴, Omer Lutfi Tapisiz ${ }^{3} \square$, Yaprak Ustun ${ }^{1} \square$ \\ ${ }^{1}$ Department of Obstetrics and Gynecology, University of Health Sciences, Etlik Zubeyde Hanım Women's \\ Health Training and Research Hospital, Ankara, Turkey \\ ${ }^{2}$ Department of Anesthesiology and Renanimation, University of Health Sciences, Ankara Training and \\ Research Hospital, Ankara, Turkey \\ ${ }^{3}$ Department of Obstetrics and Gynecology, Guven Hospital, Ankara, Turkey
}

\begin{abstract}
First identified in Wuhan of China, the novel coronavirus disease 2019 (COVID-19) is a respiratory tract infection with a global public health emergency. Data regarding COVID-19 in pregnancy is limited, consisting of case reports and small cohort studies. Postpartum urosepsis is also a globally common disease and well documented. Postpartum patients with sepsis findings should be tested for COVID-19 during outbreak for public health and patients' well-being. The clinical characteristics of urosepsis might be similar to COVID-19 disease in postpartum patients. Here, we reported the clinical management of a case with acute respiratory disorder and septic shock due to urosepsis in the postpartum period, mimicking COVID-19 infection.
\end{abstract}

Keywords: Severe acute respiratory syndrome; coronavirus; pandemic; postpartum urosepsis; pneumonia; pregnancy

\section{Öz}

İlk olarak Çin'in Wuhan kentinde tanımlanan yeni tip koronavirüs hastalığı (COVID-19), küresel bir halk sağlığı sorunu olan, bir çeşit solunum yolu enfeksiyonudur. Vaka raporları ve küçük kohort çalışmalarından oluşan, gebelikte COVID-19 ile ilgili veriler sınırlıdır. Doğum sonrası ürosepsis de küresel olarak yaygın bir hastalıktır ve pekçok yayın bulunmaktadır. Sepsis bulguları olan postpartum hastalar, salgın sırasında; halk sağlığı ve hastanın kendi iyiliği açısından COVID-19 için test edilmelidir. Ürosepsisin klinik özellikleri, doğum sonrası hastalarda COVID-19 hastalığına benzer olabilir. Bu olgu sunumu ile; postpartum dönemde ani akut solunum bozukluğu ve septik şok bulguları geliştiren bir vakada COVID-19 enfeksiyonu ve ürosepsis ayırıcı tanısının ve tedavisinin nasıl yönetildiğini anlatmak amaçlanmıştır.

Anahtar Kelimeler: Şiddetli akut respiratuvar sendrom; koronavirus; pandemi; postpartum ürosepsis; pnömoni; gebelik

Corresponding author*: Mujde Can Ibanoglu, MD, Department of Obstetrics and Gynecology, University of Health Sciences, Etlik Zubeyde Hanım Women's Health Training and Research Hospital, Ankara, Turkey,

e-mail: drmujdecan@gmail.com

Doi: $10.46969 /$ ezh.835911

ORCID: 0000-0002-8413-2064

Received: 04.12.2020

Accepted: 13.06.2021 


\section{Introduction}

Sepsis is a globally common cause of maternal mortality and morbidity with a rate of $14 \%$ (1). For the definition of sepsis, two or more of the symptoms specified in addition to the infection must be present: body temperature 38 degrees and above or 36 degrees below, heart rate greater than 90 beats/ min, a respiratory rate greater than 20 per minute, white blood cell count more than 12,000 or less than 4,000 . Septic shock is defined as sepsis with arterial hypotension that does not improve despite sufficient hydration (2). This clinical condition may lead to multiple organ failure and is mainly accompanied by hypoperfusion and hypotension (3). COVID-19 has a high and increasing attack rate and was announced as a pandemic by World Health Organization (WHO) on March 11, 2020 (4). The symptoms of the disease caused by the responsible virus, SARS-CoV-2, exhibit a broad spectrum of manifestations from asymptomatic patients to severe pneumonitis with multiple organ failure (5). Polymerase chain tests (PCR) are applied as the gold standard for diagnostic purposes, yet their sensitivity is unknown (6). Abnormalities in routine blood tests are not familiar, yet leucopenia, anaemia, low platelet levels, increased prothrombin time, elevated serum transaminases and acute phase reactants may be observed $(7,8)$.

The type of tachypnea, tachycardia, and hypotension observed in COVID-19 related pneumonia seem to share the same characteristics with postpartum septic shock. Here, we reported the clinical management of a case with acute respiratory disorder and septic shock due to urosepsis in the postpartum period, mimicking COVID-19 infection.

\section{Case Presentation}

The case was a 26-year-old G1P0 patient with 41 weeks of pregnancy. The patient applied to a tertiary healthcare institution for delivery. During admission, the patient had the following findings: Blood pressure (BP) 100/80 $\mathrm{mmHg}$; temperature, $36.2^{\circ} \mathrm{C}$; heart rate $(\mathrm{HR}), 82 \mathrm{bpm}$; and respiratory rate, $18 / \mathrm{min}$. The patient's medical history showed no contact with COVID-19. There was no known history of comorbid diseases and drug intake in the patient's history.

Urinalysis and urinary culture test had been applied to the patient as a part of the routine examination of the first admission to the hospital. Other biochemistry, hemogram and coagulation tests were within normal limits. The patient delivered a healthy infant. Approximately six hours after delivery, the patient experienced hypotension (BP: $80 / 40 \mathrm{mmHg}$ ) and tachycardia
(HR: 130 bpm). Physical examination revealed normal cervical, vulvar and vaginal examination with no active vaginal bleeding. There was no finding showing acute blood loss. No fluid was observed in the abdomen in the transvaginal ultrasound, and the uterine tonus was evaluated as usual.

Laboratory tests resulted in following values: hemoglobin level as $8.3 \mathrm{~g} / \mathrm{dL}$, white blood cell $0.81^{*} 10^{3} / \mu \mathrm{L}$, platelet $105^{*} 10^{3} /$ $\mathrm{mm}^{3}$, CRP $93.9 \mathrm{mg} / \mathrm{L}, \mathrm{D}$-dimer $7710 \mu \mathrm{g} / \mathrm{L}$ and lymphocyte $0.19 * 10^{3} / \mu \mathrm{L}$. The patient's oxygen saturation has decreased to $80 \%$, early tachypnea started $(30-35 / \mathrm{min})$, and the previous tachycardia and hypotension continued to persist. Repeated biochemistry panel showed a prothrombin time of $19.8 \mathrm{sec}$., creatinine of $1.3 \mathrm{mg} / \mathrm{dL}$, AST of $44 \mathrm{U} / \mathrm{L}$ and direct bilirubin of $2.2 \mathrm{mg} / \mathrm{dL}$. The patient was interned to an isolated positivepressure room upon these findings and the suspicion of COVID-19 or pulmonary embolism. Nasopharyngeal and oropharyngeal specimens were collected through personal protective equipment for COVID-19 PCR test, and chest x-rays were obtained (Figure 1). During the auscultation, basal parts of the left lung had diminished sounds. Anti-embolism socks were used for mechanic prevention to reduce the risk of embolism because anti-coagulant therapy could not be initiated since prothrombin time was prolonged and acute blood loss was possible. The laboratory abnormalities were interpreted as the beginning of multiple organ failure; therefore, the patient was taken to the intensive care unit upon suspicion of sepsis, disseminated intravascular coagulation, pulmonary embolism, thrombocytic thrombocytopenic purpura (TTP), and COVID -19. Abdominal ultrasound showed splenomegaly and ascites in the abdomen as well as increased parenchymal echogenicity in both kidneys. Echocardiography was normal. With no abnormal imaging finding of lungs and the heart, arterial blood gas parameters revealed pO2 of $45.5 \mathrm{mmHg}$, sO2 of $79.1 \%$, lactate of $1.7 \mathrm{mmol} / \mathrm{L}$ and no increment of the D-dimer, ruling out a pulmonary embolism. Since there was no decrease in platelet values and there were no additional findings of hemolysis, the diagnosis of TTP was excluded.

Since no fever was observed, COVID-19 based antiviral therapy was postponed until the release of test results. Meanwhile, the following values shifted the diagnostic workup on septic conditions: procalcitonin $62.71 \mu \mathrm{g} / \mathrm{L}$, direct bilirubin $2.2 \mathrm{mg} /$ $\mathrm{dL}$, lactate dehydrogenase $803 \mathrm{U} / \mathrm{L}$, platelet $45,000 / \mathrm{mm}^{3}$, and creatinine $2.3 \mathrm{mg} / \mathrm{dL}$. The patient was treated with vancomycin, carbapenem, and inhaled corticosteroids. The patient was removed from isolation and the treatment was maintained with 
continuous positive airway pressure after a negative PCR result. The PCR test was repeated 24 hours later since the patient's clinical diagnosis had yet to be made. The diagnosis of COVID-19 was eliminated upon the second negative test result. During the first admission, the urinary culture collected from the patient revealed E.coli formation of $100.000 \mathrm{CFU} / \mathrm{mL}$, leading to discontinuance of the steroid treatment and maintenance of antibiotic treatment. The patient was discharged on the $10^{\text {th }}$ postpartum day and prescribed oral antibiotic together with low-molecular-weight heparin (LMWH). Meanwhile, the baby was isolated from the mother and home-based care was given. Breastfeeding was not recommended since the mother's general condition was not eligible due to the risk of infection. Breastfeeding resumed after the second negative test result. The patient and the baby did not develop any symptoms of COVID-19 as of the $40^{\text {th }}$ day of the postpartum period. Excluding other pathological conditions, the diagnosis was established as postpartum urosepsis based on treatment response.

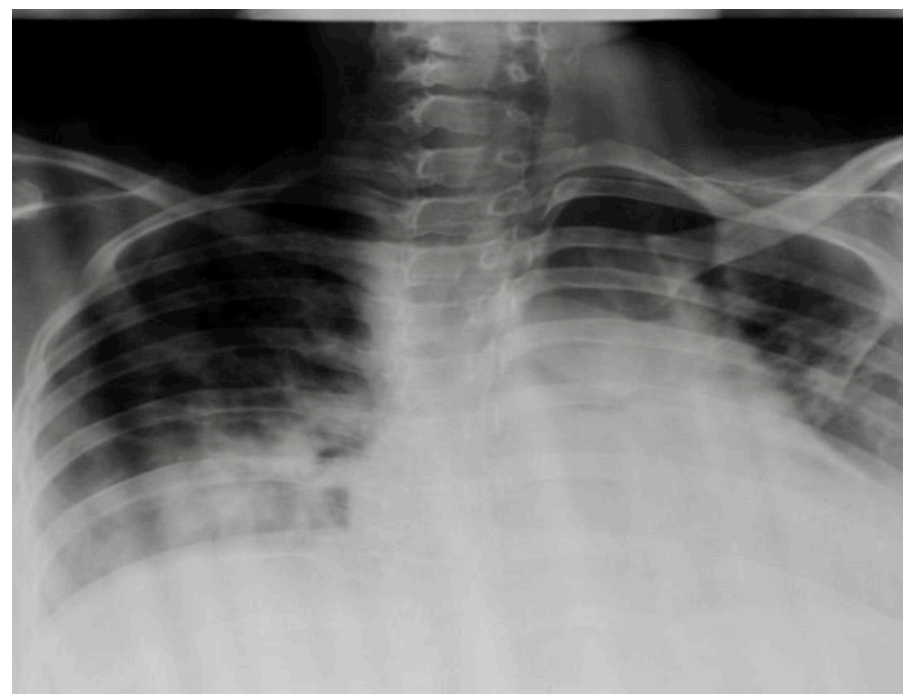

Figure 1. The view of the posteroanterior chest X-ray of the patient

\section{Discussion}

Our patient had a progressively worsening condition that started with tachycardia, tachypnea, and hypotension, also evident by laboratory tests. Postpartum haemorrhage, COVID-19 and pulmonary embolism were initially included in the differential diagnosis. Symptomatic treatment was administered until the test results were yielded as no standard agreed treatment protocol was determined for the pandemic, followed by removing isolation measurements upon negative test results. The anticoagulant therapy was not started because of the acute bleeding risk; however, after the risk was over, LMWH treatment was initiated.
The patient's clinical status was not fully defined; therefore, the test was repeated - 24 hours later- and COVID-19 was ruled out on the 4th postpartum day upon the second negative test result. PCR tests are known to yield false-negative results. Hence, repeating PCR tests on the patients suspected to be infected with the SARS-CoV-2 was recommended (6).

The studies conducted have shown that the SARS-CoV-2 has the same course among pregnant and non-pregnant individuals. Vertical contamination of the fetus has yet to be observed (9). Even though; there is no vertical transition, the infant was isolated considering that there might be a passage through the respiratory tract or COVID-19 shedding into breast milk (10).

Urinary tract infection develops in up to $4 \%$ of patients after birth (11). Increasing bladder volume due to increased estrogen and progesterone in the puerperium, as resulting from decreased bladder tone with ureterovesical reflux, is seen as an increased risk factor for infection (12). There are no adequate guidelines and information about infections, which rank the third reason in maternal deaths worldwide, and as a result, it becomes a clinical picture that quickly escapes the attention of clinicians and has an significant result. Transition to rapid diagnosis and treatment is also very critical and life-saving in maternal sepsis. The first evaluation should be done quickly and blood and other culture samples and blood lactate levels should be taken (13). Appropriate antibiotic treatment should be initiated within an hour, intravenous fluid balance should be regulated, and a transition to the intensive care unit should be provided (12).

The patient was diagnosed with postpartum urosepsis because of her response to the antibiotic treatment given and the positivity of E. Coli in the urine culture. It may be suggested that postpartum patients with such symptoms need to be followed with a balanced and careful approach to not focus on any possible diagnosis more than the other.

In conclusion, it is essential in differential diagnosis to consider sepsis together with COVID-19. Treatment modalities and protective measures that consider the benefit of both individuals and public health should be arranged comprehensively.

\section{Ethical approval and informed consent agreement}

An ethics board approval for the study was obtained from the Institutional Review Board. The patient gave written informed consent that allowed us to use her data.

\section{Funding}

None 


\section{References}

1. Maharaj D. Puerperal pyrexia: a review. Part I. Obstetrical \& gynecological survey. 2007; 62:393-399.

2. Bone RC, Balk RA, Cerra FB, Dellinger RP, Fein AM, Knaus WA, et al. Definitions for sepsis and organ failure and guidelines for the use of innovative therapies in sepsis. Chest 1992; 101:1644-1655.

3. Bone RC, Sprung CL, Sibbald WJ. Definitions for sepsis and organ failure. Crit Care Med 1992; 20:724-726.

4. Dhama K, Khan S, Tiwari R, et al. Coronavirus Disease 2019-COVID-19. Clin Microbiol Rev 2020; 33:e00028-20.

5. Covid TC, Team R. Severe Outcomes Among Patients with Coronavirus Disease 2019 (COVID-19)-United States, February 12-March 16, 2020. MMWR Morb Mortal Wkly Rep. 2020; 69:343-346.

6. Organization WH. Laboratory testing for coronavirus disease 2019 (COVID-19) in suspected human cases: interim guidance, 2 March 2020. World Health Organization, 2020.

7. Huang $C$, Wang $Y, L i X$, et al. Clinical features of patients infected with 2019 novel coronavirus in Wuhan, China. Lancet. 2020; 395:497-506.
8. Chen N, Zhou M, Dong X, et al. Epidemiological and clinical characteristics of 99 cases of 2019 novel coronavirus pneumonia in Wuhan, China: a descriptive study. Lancet 2020; 395:507-13.

9. Mullins E, Evans D, Viner RM, O'Brien P, Morris E. Coronavirus in pregnancy and delivery: rapid review. Ultrasound Obstet Gynecol 2020; 55:586-592.

10. De Rose DU, Piersigilli F, Ronchetti MP, et al. Novel Coronavirus disease (COVID-19) in newborns and infants: what we know so far. Ital J Pediatr 2020; 46:56.

11. van Dillen J, Zwart J, Schutte J, van Roosmalen J. Maternal sepsis: epidemiology, etiology and outcome. Current Opinion Inf Dis 2010; 23:249-254.

12. Knowles S, O'sullivan N, Meenan A, Hanniffy R, Robson M. Maternal sepsis incidence, aetiology and outcome for mother and fetus: a prospective study. BJOG 2015; 122:663-671.

13. Bamfo JE. Managing the risks of sepsis in pregnancy. Best Pract Res Clin Obstet Gynaecol 2013; 27:583-595. 